\title{
HIDDEN BUGS SALVAGE TIMBER SALE ENVIRONMENTAL ASSESSMENT
}

\author{
Montana Department of \\ Natural Resources and Conservation \\ Southwestern Land Office \\ Clearwater Unit
}

April 2007

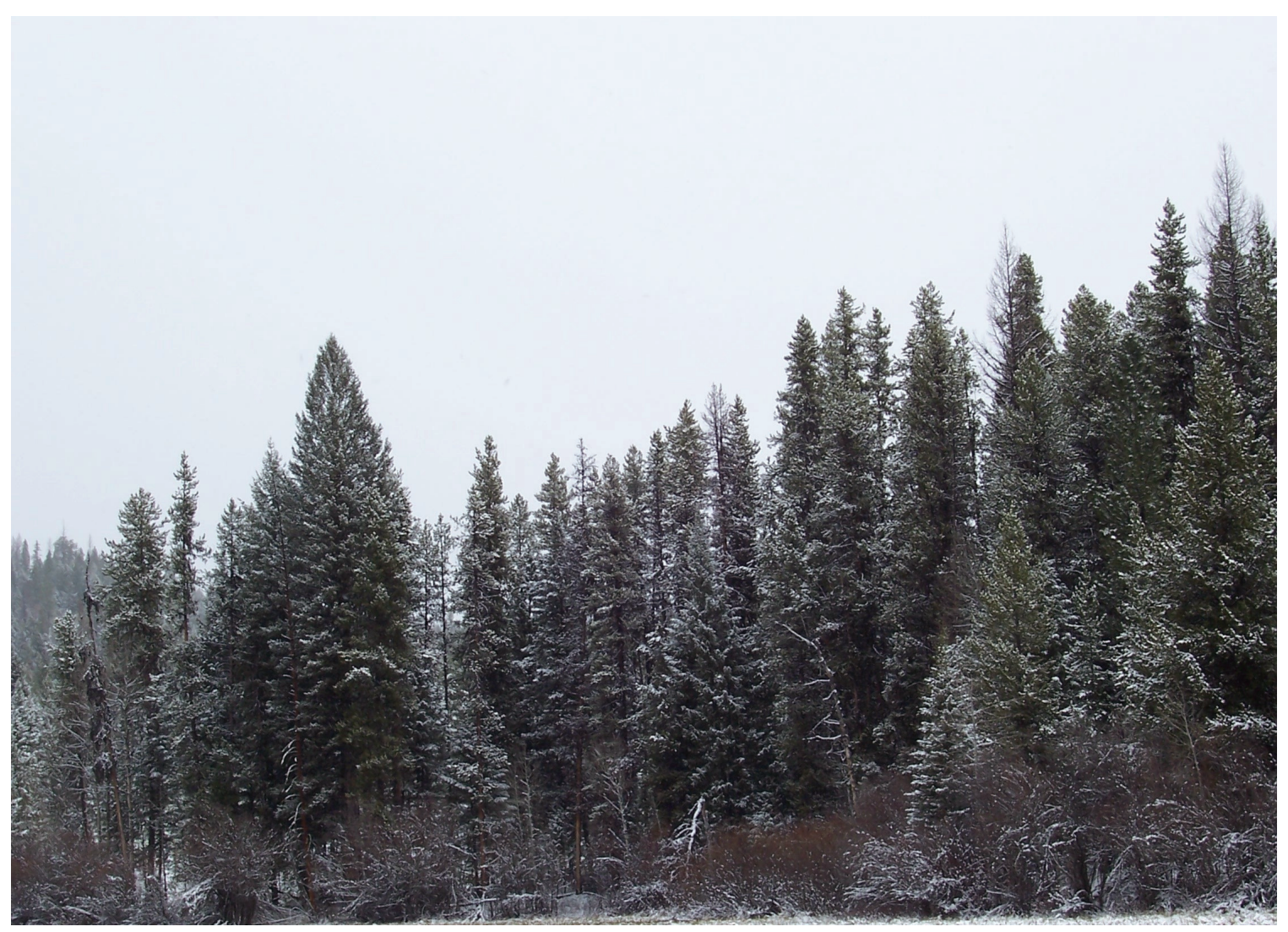




\section{HIDDEN BUGS SALVAGE TIMBER SALE ENVIRONMENTAL ASSESSMENT}

\section{TABLE OF CONTENTS}

Checklist EA: 8 pages

Appendix A, Vicinity map: 1 page

Appendix B, Sale Map: 1 page

Appendix C, Watershed and Soils Analysis: 7 pages

Appendix D, Wildlife Analysis: 18 pages

Appendix E, Initial Proposal: 1 page 


\section{CHECKLIST ENVIRONMENTAL ASSESSMENT}

\begin{tabular}{|ll|}
\hline Project Name: & Hidden Bugs Salvage Timber Sale \\
Proposed & \\
Implementation Date: & Summer 2007 through Fall 2008 \\
Proponent: & Montana Department of Natural Resources and Conservation, Clearwater Unit \\
Location: & Section 18, Township 16 North, Range 15 West \\
County: & Missoula \\
\hline
\end{tabular}

\section{TYPE AND PURPOSE OF ACTION}

The Clearwater Unit of the Montana Department of Natural Resources and Conservation (DNRC) is proposing to harvest an estimated 800 thousand board feet of timber from approximately 125 acres. The proposed harvest area is located about 4 miles southwest of Seeley Lake, in Section 18 of Township 16 North, Range 15 West (Attachment A, Vicinity Map). Under the proposed action, DNRC would harvest lodgepole pine that is dead, dying, and susceptible to mountain pine beetle attack. Approximately 4 miles of road maintenance, $1 / 2$ mile of road building, and $1 / 4$ mile of road abandonment would occur. If the Action Alternative is selected, activities could begin in July 2007. Implementation of the proposed harvest would generate an estimated $\$ 160,000$ in revenue to the M.S.U. $2^{\text {nd }}$ Grant.

The lands involved in this proposed project are held by the State of Montana in trust for the M.S.U. $2^{\text {nd }}$ Grant (Enabling Act of February 22, 1889; 1972 Montana Constitution, Article X, Section 11). The Board of Land Commissioners and the DNRC are required by law to administer these trust lands to produce the largest measure of reasonable and legitimate return over the long run for the beneficiary institutions (Section 77-1-202, MCA). Specific objectives of the project are to capture value of dead and dying trees, prevent future value loss, and promote appropriate forest types within the project area. Secondary objectives are to improve the transportation system, reduce fuel loading within stands, and control the spread of noxious weeds.

\section{PROJECT DEVELOPMENT}

\section{PUBLIC INVOLVEMENT, AGENCIES, GROUPS OR INDIVIDUALS CONTACTED:}

Provide a brief chronology of the scoping and ongoing involvement for this project.

DNRC sent scoping letters on January 11, 2007 to adjacent landowners and other interested parties (Appendix E, initial proposal). A public notice was run in the Missoulian and Seeley Swan Pathfinder; notices were also posted at the Seeley Lake Post Office and Rovero's Gas Station. Six written comment letters and one phone call were received and used to identify concerns and modify the proposed action. DNRC specialists were consulted, including: Mike McGrath, Wildlife Biologist; Jeff Collins, Hydrologist; and Patrick Rennie, Archeologist. Sarah Pierce prepared this environmental assessment and Craig Nelson, Forest Management Supervisor of the Clearwater Unit, will be the decision maker

\section{OTHER GOVERNMENTAL AGENCIES WITH JURISDICTION, LIST OF PERMITS NEEDED:}

Slash burning would be done in compliance with statewide cooperative agreements as well as any local restrictions. 


\section{ALTERNATIVES CONSIDERED:}

No Action: None of the proposed harvest or roadwork would occur at this time. Current land use activities would continue.

Timber Harvest Alternative: Under this alternative, DNRC would continue current uses, and also harvest lodgepole pine. Dead and dying lodgepole pine, as well as those highly susceptible to mountain pine beetle, would be harvested. The harvest would include salvage of individual and groups of lodgepole within stands currently infested by mountain pine beetle. All other species would be retained unless within a skid trail or landing area. Up to 800 thousand board feet would be harvested from approximately 125 acres (Attachment B, Proposed Harvest Units and Roads Map). The majority of this would be harvested by one timber sale in the late summer and autumn of 2007. One six-acre harvest unit, that would require winter operations, could be sold as a subsequent timber permit. Timber would be harvested with ground-based methods. The harvest activity may require the construction of approximately $1 / 2$ mile of low standard road and the maintenance and use of existing roads on both state and private land as designated haul routes. In addition, approximately $1 / 4$ mile of existing road would be abandoned and one or more gates or other road closures may be installed.

No Harvest Alternative: During scoping for the proposed project, one commenter suggested an alternative to carry out only restoration activities, specified as an alternative to remove or fix roads with design flaws. This alternative would not meet the project objective of capturing timber values, and would not be economically feasible to carry out, so it was not studied in detail. However, DNRC shares the concerns about roads and did incorporate road improvements and abandonment into the timber harvest alternative.

\section{IMPACTS ON THE PHYSICAL ENVIRONMENT}

- $\quad$ RESOURCES potentially impacted are listed on the form, followed by common issues that would be considered.

- Explain POTENTIAL IMPACTS AND MITIGATIONS following each resource heading.

- Enter "NONE" If no impacts are identified or the resource is not present.

\section{GEOLOGY AND SOIL QUALITY, STABILITY AND MOISTURE:}

Consider the presence of fragile, compactable or unstable soils. Identify unusual geologic features. Specify any special reclamation considerations. Identify any cumulative impacts to soils.

No substantial direct, indirect or cumulative impacts to soils resources are expected to result from implementation of the proposed action alternative. No unstable slopes or unique geology features are present. Geology is stable quartzites and argillites overlain by glacial till deposits. Predominate forest soils are Winfall gravelly loams on $4-30 \%$ slopes (small areas up to $40 \%$ ) forming in deep glacial till. Erosion risk is moderate where soils are disturbed. Low levels of short-term on-site erosion of road surfaces, cut slopes and fill slopes are expected during and shortly after road construction, while revegetation establishes. Proposed harvest units include areas of past (>30 yrs ago) selection harvest. Proposed harvest would use existing roads and segments of existing skid trails where feasible. Planned ground skidding operations should have low direct, in-direct and cumulative impacts based on implementing BMP's and mitigation measures. Mitigations include season of use limits, general skidding plans, retaining woody debris for nutrients and prompt revegetation of disturbed sites on roads to protect soil resources.

For detailed analysis, please refer to Attachment C, Soils, Watershed, and Fisheries Report.

\section{WATER QUALITY, QUANTITY AND DISTRIBUTION:}

Identify important surface or groundwater resources. Consider the potential for violation of ambient water quality standards, drinking water maximum contaminant levels, or degradation of water quality. Identify cumulative effects to water resources.

No substantial direct, indirect or cumulative impacts to water quality, water quantity or downstream beneficial uses are expected to result from implementation of the proposed action alternative. The proposed salvage harvest of dead, dying and high risk trees would have a minor reduction of canopy cover and no measurable water yield increase compared to the current conditions and trend for reduced canopy. There is a discontinous stream within the project area that ends in a meadow and there is no steam connectivity off the projcet area. Low levels of short-term on-site erosion of road surfaces, cut slopes and fill slopes during and shortly after road construction, abandonment, or obliteration can be expected while revegetation becomes established 
There is low potential risk of sediment delivery from proposed and existing roads. DNRC will mark and maintain suitable water resource protection boundaries (SMZ's, RMZ's, WMZ's) adjacent to the discontinuous stream and wetlands consistent with State Forest Land Management rules and applicable laws.

For detailed analysis, please refer to Attachment C, Soils, Watershed, and Fisheries Report.

\section{6. $\quad$ AIR QUALITY:}

What pollutants or particulate would be produced? Identify air quality regulations or zones (e.g. Class I air shed) the project would influence. Identify cumulative effects to air quality.

Under the action alternative, there would be some influence to local airsheds. Over $70 \%$ of the emissions emitted from prescribed burning is less than 2.5 microns (National Ambient Air Quality PM 2.5). High, shortterm levels of PM 2.5 may be hazardous. Within the typical column of biomass burning, the chemical toxics are: Formaldehyde, Acrolein, Acetaldehyde, 1,4 Butadiene, and Polycyclic Organic Matter.

Federal, state and local agencies enforce rules for open, controlled burning. The post thinning burning of piled debris would produce particulate matter. All burning would be conducted at times of adequate ventilation and within existing rules, plans, and regulations. Air quality is analyzed by estimating emissions from prescribed burns. The air quality analysis area for the proposed action is located in Montana Airshed 3B. The Montana Airshed Group is responsible for determining both air shed number and impact zones. The project area is not located in any of the impact zones.

Prior to burning be used, a "Prescribed Fire Burn Plan" would be been done for the area.

Cumulative effects to air quality would not exceed the levels defined by State of Montana Cooperative Smoke Management Plan (1988) and managed by the Montana Airshed Group. Prescribed burning by other nearby airshed cooperators (for example Plum Creek Timber Company) would have potential to affect air quality. All cooperators currently operate under the same Airshed Group guidelines. The State, as a member, would burn only on approved days. This should decrease the likelihood of additive cumulative effects.

\section{VEGETATION COVER, QUANTITY AND QUALITY:}

What changes would the action cause to vegetative communities? Consider rare plants or cover types that would be affected. Identify cumulative effects to vegetation.

The project area (section 18) consists primarily of mixed conifer, Douglas-fir/western larch, and subalpine fir cover types. All of these cover types have a component of lodgepole pine. Approximately 289 acres (98\%) of the 296 acre project area is forested. Most (234 acres) of the project area is in the sawtimber size class and has medium or high total stocking. Stands within the project area currently have a high susceptibility and risk of mountain pine beetle damage, based on the species, age, stand density, elevation, and existing mountain pine beetle presence. Lodgepole pine within the project area are dead, infested, or at risk.

At the larger scale, DNRC lands managed by the Clearwater Unit are approximately $85 \%$ forested, mostly in the ponderosa pine and western larch/Douglas-fir cover types. Compared to the desired future condition at this scale, Douglas-fir, subalpine fir, and mixed-conifer cover types are slightly over-represented while ponderosa pine and western larch/Douglas-fir are slightly under-represented. Overall, however, about $84 \%$ of these lands do have a cover type that matches the desired future condition. This area falls within climatic section 332B, which was historically about $79 \%$ forested. Within the climatic section, the historically dominant cover type was lodgepole pine, followed by Douglas-fir and ponderosa pine on lower slopes (Losensky, 1997).

DNRC has adopted old-growth definitions based on Green et al. (1992). None of the stands in the project area meet DNRC's definition of old-growth. No recorded threatened, endangered, or sensitive plant species were found in the project area (MNHP, 2007). A concern was raised that the area is susceptible to noxious weeds.

No Action: No harvest would occur at this time. Compared to the existing condition, no immediate changes would be expected. Mountain pine beetle would likely continue to infest and kill lodgepole and ponderosa pine within the DRNC ownership and surrounding area. Some of the dead trees would likely be blown down, creating openings within the stands. Over time, some natural conifer regeneration would probably establish in areas with a seed source and favorable microclimate. Weed treatment could occur as funding allows.

Timber Harvest Alternative: DNRC would harvest and remove lodgepole pine that are dead, dying, or highly susceptible to mountain pine beetle attack. Changes to the vegetation would include an immediate reduction in numbers of live and dead lodgepole pine on 125 acres. Other species, including ponderosa pine, western larch, 
and Douglas-fir would be retained. One of the largest available snags or snag recruits per acre would be retained. The proposed harvest would reduce stems per acre in the harvest units, which cover $42 \%$ of the project area. The cover types would remain the same, although the component of lodgepole pine would be reduced in all harvested stands. The remaining trees would have increased growth as more resources would be available per tree. While regeneration is not a goal of the prescription, some lodgepole and Douglas-fir would likely become established through natural regeneration in openings. In addition, DNRC would plant appropriate species for the site (western larch, ponderosa pine, Douglas-fir) in larger openings. On the adjacent Forest Service ground, the proposed fuel reduction project would reduce stand density on 388 acres. Over time, other adjacent land would grow from sapling to pole and sawtimber size classes of mixed conifer species. At the larger scale, the proposed harvest in combination with other current and potential salvage projects would reduce stand density on less than $1 \%$ of the area managed by the Clearwater Unit.

No sensitive plants have been identified in the project area. To prevent introduction of new weeds, off-road equipment will be cleaned and inspected prior to entry into harvest areas. Newly disturbed roads and landing will be seeded to grass. Roadsides with existing weed would be controlled with herbicide The proposed action would be expected to result in minor direct, indirect, and cumulative impacts on forest vegetation.

\section{TERRESTRIAL, AVIAN AND AQUATIC LIFE AND HABITATS:}

Consider substantial habitat values and use of the area by wildlife, birds or fish. Identify cumulative effects to fish and wildlife.

Please refer to Attachment D, Wildlife Report, and Attachment C, Soils, Watershed, and Fisheries Report.

\section{UNIQUE, ENDANGERED, FRAGILE OR LIMITED ENVIRONMENTAL RESOURCES:}

Consider any federally listed threatened or endangered species or habitat identified in the project area. Determine effects to wetlands. Consider Sensitive Species or Species of special concern. Identify cumulative effects to these species and their habitat.

Refer to Attachment D Wildlife Report, and Attachment C, Soils, Watershed, and Fisheries Report.

\section{HISTORICAL AND ARCHAEOLOGICAL SITES:}

Identify and determine effects to historical, archaeological or paleontological resources.

Based on the topography of the sale area and lack of previously identified cultural resources, DRNC Archaeologist Patrick Rennie did not recommend additional investigative work. If any archaeological sites are found, they would be protected. No direct, indirect, or cumulative effects to cultural resources are expected as a result of the proposed action.

\section{AESTHETICS:}

Determine if the project is located on a prominent topographic feature, or may be visible from populated or scenic areas. What level of noise, light or visual change would be produced? Identify cumulative effects to aesthetics.

The proposed sale area is not visible from any populated areas. Portions of the section are visible from slopes to the south and east of the area. Within the project area, harvested stands would look more open with fewer trees per acre. Viewed from a further distance, the harvest would create openings that would fill in over time. These would blend in with the existing mosaic of openings and dense areas on surrounding ownerships. The proposed project would be expected to have a low risk of negatively affecting the aesthetic quality of the area. Some noise from harvesting equipment and log hauling may be heard within the project area and on haul routes. This is expected to be short in duration and temporary. Due to the location, the relatively small area and the short duration of the proposed project, there would be no measurable cumulative effects on aesthetics.

\section{DEMANDS ON ENVIRONMENTAL RESOURCES OF LAND, WATER, AIR OR ENERGY:}

Determine the amount of limited resources the project would require. Identify other activities nearby that the project would affect. Identify cumulative effects to environmental resources.

No impacts are likely to occur under either alternative. 


\section{OTHER ENVIRONMENTAL DOCUMENTS PERTINENT TO THE AREA:}

List other studies, plans or projects on this tract. Determine cumulative impacts likely to occur as a result of current private, state or federal actions in the analysis area, and from future proposed state actions in the analysis area that are under MEPA review (scoped) or permitting review by any state agency.

In 1986, DNRC completed the Hidden Lake Timber Sale, which included 60 acres of harvest within section 18. The harvest units were small clearcut and seedtree units that have since regenerated into lodgepole and mixed conifer sapling stands. DNRC's stand level inventory, used for analyses in this environmental assessment, reflects the past harvest and current conditions of those stands. At the scale of the Clearwater Unit, two additional salvage sales totaling 297 acres are ongoing or have been scoped. Some private ownerships are currently harvesting timber in neighboring parcels. The Lolo National Forest is planning the Hidden Lakes Fuels Reduction project in section 13 of Township 16N, Range 16W, adjacent to the western boundary of DNRC's section 18. This project would include 388 acres of fuels reduction and construction of temporary and shortterm road.

\section{IMPACTS ON THE HUMAN POPULATION}

- $\quad$ RESOURCES potentially impacted are listed on the form, followed by common issues that would be considered.

- Explain POTENTIAL IMPACTS AND MITIGATIONS following each resource heading.

- Enter "NONE" If no impacts are identified or the resource is not present.

\section{HUMAN HEALTH AND SAFETY:}

Identify any health and safety risks posed by the project.

Human health would not be impacted by the proposed timber sale or associated activity. Safety considerations and temporary risks would increase for the professional contractors working within the sale area. Log truck traffic would increase but safety concerns would be minimized by posting signs and imposing a speed limit for log trucks on shared roads. There are no unusual safety considerations associated with the proposed timber sale. The general public and local residents would not face increased health or long term safety hazards because of the proposed timber sale.

\section{INDUSTRIAL, COMMERCIAL AND AGRICULTURE ACTIVITIES AND PRODUCTION:} Identify how the project would add to or alter these activities.

The section is not currently leased for grazing. Over time as openings are created by harvesting or dying trees, forage production would be expected to increase slightly under either alternative.

\section{QUANTITY AND DISTRIBUTION OF EMPLOYMENT:}

Estimate the number of jobs the project would create, move or eliminate. Identify cumulative effects to the employment market.

People are currently employed in the wood products industry in the region. Due to the relatively small size of the timber sale, there would be no measurable cumulative impact from this proposed action on employment.

\section{LOCAL AND STATE TAX BASE AND TAX REVENUES:}

Estimate tax revenue the project would create or eliminate. Identify cumulative effects to taxes and revenue.

People are currently paying taxes from the wood products industry in the region. Due to the relatively small size of the timber sale, there would be no measurable cumulative impact from this proposed action on tax revenues.

\section{DEMAND FOR GOVERNMENT SERVICES:}

Estimate increases in traffic and changes to traffic patterns. What changes would be needed to fire protection, police, schools, etc.? Identify cumulative effects of this and other projects on government services

Aside from contract administration, there would be minimal impact related to demand for government services due to the relatively small size of the timber sale, the short-term impacts to traffic, and the small possibility of a few people temporarily relocating to the area. 


\section{LOCALLY ADOPTED ENVIRONMENTAL PLANS AND GOALS:}

List State, County, City, USFS, BLM, Tribal, and other zoning or management plans, and identify how they would affect this project.

The DNRC operates under the State Forest Land Management Plan (SFLMP, DNRC 1996) and Administrative Rules for Forest Management (ARM 36.11.401 through 450, DNRC 2003). The SFLMP established the agency's philosophy for management of forested trust lands. The Administrative Rules provide specific guidance for implementing forest management projects.

\section{ACCESS TO AND QUALITY OF RECREATIONAL AND WILDERNESS ACTIVITIES:}

Identify any wilderness or recreational areas nearby or access routes through this tract. Determine the effects of the project on recreational potential within the tract. Identify cumulative effects to recreational and wilderness activities.

This section is open year round for non-motorized public access. Some snowmobile use does occur in the general area during the winter. There are no wilderness areas in the vicinity. Under the action alternative, one or more gates may be installed to continue limiting access to non-motorized use. Slash within harvest units may decrease walk-in traffic. Winter harvest of one six-acre unit would include some hauling approximately 1 mile of road that may also be used by snowmobiles. This would be of short duration and on an open road that is shared by log trucks, other vehicles, and snowmobiles on a regular basis. Due to the context and intensity of the proposed action, no measurable effects to access and recreation are expected.

\section{DENSITY AND DISTRIBUTION OF POPULATION AND HOUSING:}

Estimate population changes and additional housing the project would require. Identify cumulative effects to population and housing.

There would be no measurable cumulative impacts related to population and housing due to the relatively small size of the timber sale, and the fact that people are already employed in this occupation in the region.

\section{SOCIAL STRUCTURES AND MORES:}

Identify potential disruption of native or traditional lifestyles or communities.

No measurable impacts related to social structures and mores would be expected under either alternative.

\section{CULTURAL UNIQUENESS AND DIVERSITY:}

How would the action affect any unique quality of the area?

No measurable impacts related to cultural uniqueness and diversity would be expected under either alternative.

\section{OTHER APPROPRIATE SOCIAL AND ECONOMIC CIRCUMSTANCES:}

Estimate the return to the trust. Include appropriate economic analysis. Identify potential future uses for the analysis area other than existing management. Identify cumulative economic and social effects likely to occur as a result of the proposed action.

No Action: A recreational license for outfitting on the DNRC parcel would continue to generate estimated annual revenue of $\$ 25.00$.

Timber Harvest Alternative: Revenue from the recreational license would continue. The timber harvest would generate additional revenue for the M.S.U. $2^{\text {nd }}$ Trust. The estimated return to the trust for the proposed harvest is $\$ 160,000$ based on an estimated harvest of 800 thousand board feet and an overall stumpage value of $\$ 200.00$ per thousand board feet (MBF) (\$29.00 per ton, based on similar recent timber sales). Costs related to the administration of the timber sale program are only tracked at the Land Office and Statewide level. DNRC doesn't track project-level costs for individual timber sales. An annual cash flow analysis is conducted on the DNRC forest product sales program. Revenue and costs are calculated by land office and statewide. These revenue-to-cost ratios are a measure of economic efficiency. The most recent revenue-to-cost ratio of the Southwestern Land Office was 2.43 . This means that, on average, for every $\$ 1.00$ spent in costs, $\$ 2.43$ in revenue was generated. Costs, revenues, and estimates of return are estimates intended for relative comparison of alternatives. They are not intended to be used as absolute estimates of return.

\begin{tabular}{l|lll} 
EA Checklist & Name: & Sarah Pierce & Date: April 16, 2007 \\
Prepared By: & Title: & Forester, Clearwater Unit & \\
\hline
\end{tabular}




\section{FINDING}

\section{ALTERNATIVE SELECTED:}

Timber Harvest Alternative

\section{SIGNIFICANCE OF POTENTIAL IMPACTS:}

This Environmental Analysis has been completed for Hidden Bugs Salvage Sale. After a thorough review of the EA, project file, response to the scoping letters, Department policies, standards and guidelines, and the State Land Management Rules, I have taken the decision to choose the Timber Harvest alternative. I have found that this EA and project will achieve the following:

This project will salvage dead and dying timber before it loses its economic value. This is explained in EA part 3 Alternatives Considered, EA part 24 Other Appropriate Social and Economic Issues, and is required by law in MCA 77-5-207. The No Harvest Alternative that is discussed within part 3 of the EA will not achieve the law described within MCA 77-5-207 Salvage timber program.

This project will reduce the susceptibility of residual trees to epidemic insect and disease infestations and outbreaks. This is explained in EA part 7 Vegetation Cover, Quantity, and Quality. The project may also plant trees native to the area (Douglas-fir, western larch, and ponderosa pine) to decrease similar concerns in the future. Through treatment, this area will see decreased fuel levels and hazards against adjacent lands. This project will help control the spread of noxious weeds in the project area. This information is found in EA part 7 Vegetation Cover, Quantity, and Quality, and Attachment C Soils, Watershed, and Fisheries Report.

This project will improve the transportation system for the project area. This is described in EA part 5 Water Quality, Quantity, and Distribution. This is also described within the Attachment C Soils, Watershed, and Fisheries Report.

\section{NEED FOR FURTHER ENVIRONMENTAL ANALYSIS:}

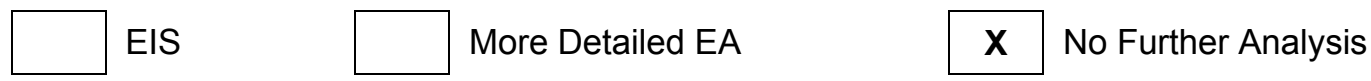

\begin{tabular}{l|ll}
\hline $\begin{array}{c}\text { EA Checklist } \\
\text { Approved By: }\end{array}$ & Name: & Craig V. Nelson \\
\cline { 3 - 3 } & Title: & Forest Management Supervisor
\end{tabular}

Signature: /s/ Craig V. Nelson

Date: April 16, 2007 


\section{References}

Department of Natural Resources and Conservation (DNRC). 1996. State Forest Land Management Plan. Montana DNRC, Forest Management Bureau. Missoula, MT.

DNRC. 2003. Montana Administrative Rules for Forest Management. Montana DNRC Trust Land Management Division, Forest Management Bureau. Missoula, MT. 87p.

Graham, R.T., A.E. Harvey, MF Jurgensen, TB Jain, JR Tonn, DS Page-Dumroese. 1994. Managing coarse woody debris in forests of the Rocky Mountain. USDA For. Serv. Int. Mtn. Res. Sta. INT-RP-477. 13pp.

Green, P., J. Joy, D. Sirucek, W. Hann, A. Zack, and B. Naumann. 1992. Old-Growth Forest Types of the Northern Region. USDA Forest Service, Region 1. Missoula, MT.

Losensky, J. 1997. Historical vegetation of Montana. Contract \#970900. Montana DNRC. Missoula, MT. 109pp.

Montana Natural Heritage Program (MNHP). 2007. Information on Plant and Animal Species of Special Concern. Report on file at DNRC Clearwater Unit. Greenough, MT. 6pp. 


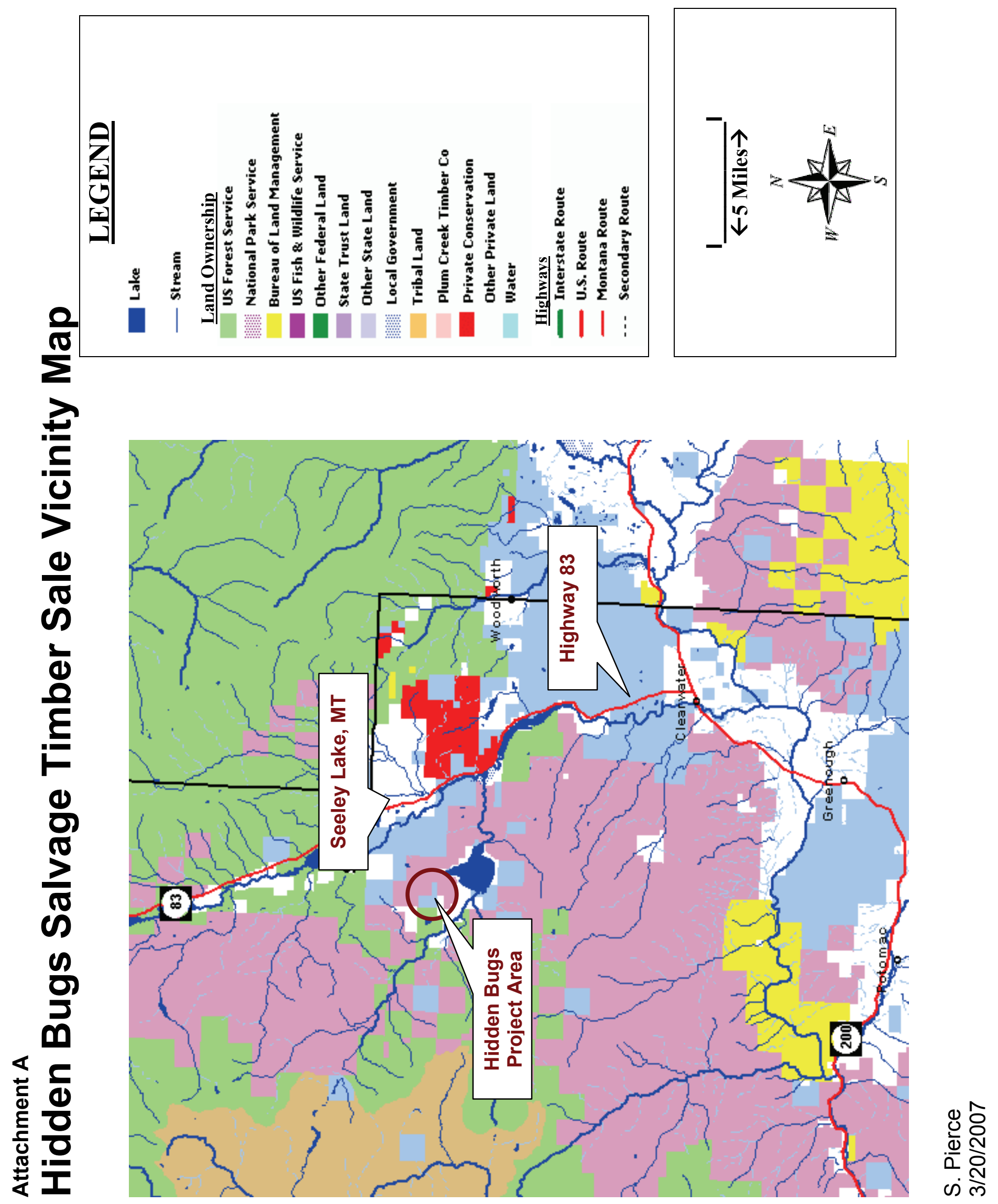




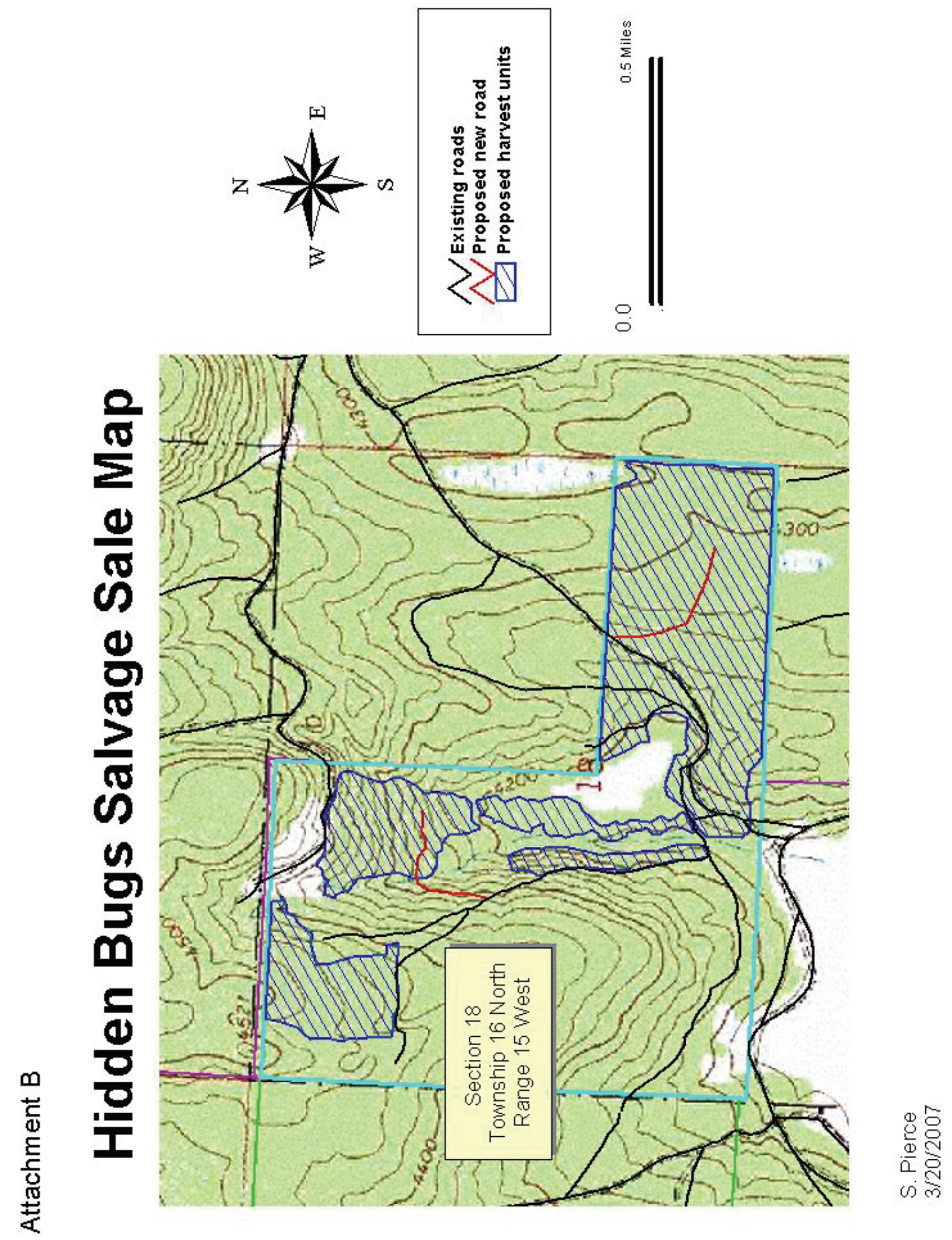




\section{Attachment C \\ Soils, Watershed, and Fisheries Report}

March 21, 2007

TO: $\quad$ SARAH PIERCE, Project Forester, Clearwater Unit STEVE WALLACE, Field Supervisor, Clearwater Unit CRAIG NELSON, Lead Forester, Clearwater Unit JON HAYES, Silviculturist, SWLO

FROM: $\quad$ JEFF COLLINS, Hydrologist

SUBJECT: $\quad$ HIDDEN BUGS TIMBER SALE, Portion of Section 18, T16N, R15W

The following includes an existing condition and effects assessment for soils, watershed, and fisheries resources for the proposed Hidden Bugs Timber Sale Environmental Assessment. The proposed timber tale would salvage harvest up to $800 \mathrm{mbf}$ of dead, dying and high risk lodgepole pine. The mortality is extensive throughout the mid to larger diameter lodgepole. This analysis is based on a coarse filter screening approach for watershed evaluation and on-site field review of the proposed sale area. The following issue statements were developed concerning water resources, soils and noxious weeds, regarding the effects of proposed timber harvest and road systems.

* Timber harvesting and road construction have the potential to increase water yield, which in turn may affect stream channel stability.

* Timber harvest and road construction may increase sediment delivery into streams and affect water quality.

* Soil resources may be impacted by harvest operations that cause excessive displacement, erosion or soil compaction depending on the area and degree of detrimental effects.

${ }^{*}$ Noxious weeds may be introduced or increased associated with harvest effects

\section{Existing Conditions: Affected Watershed,}

The proposed Hidden Bugs Timber Sale project is located within the 311 acres of state trust land ownership on Section 18, T16N, R15W of Missoula County. The terrain is gentle to moderate slopes of $5-40 \%$, on the foothill slopes approximately $1 / 2$ mile NW of Placid Lake (elev. $4149 \mathrm{ft}$.). The analysis area considers the intermittent drainage above a meadow that is mainly in section 18, and is north of Placid Creek. Refer to the following Hidden Bugs Watershed area map. The Lower Placid Creek Watershed (HUC 170102031204) is a 3rd order tributary of 21,647 acres in area and is tributary to Placid Lake and the Clearwater and Blackfoot Rivers. There is a short stream segment in the DNRC ownership, but there is no stream connectivity off site or direct channel delivery to Placid Creek.

Elevations in the section range from 4200 to 4500 feet. Precipitation ranges from 21-60" within the watershed. Average precipitation in the project section is 23 inches a year, mainly as snow. Runoff is not flashy due to low precipitation, mainly well drained soils and moderate slopes. Wetlands and meadows provide water storage, buffer surface flows and retain on-site sediments. The proposed harvest units are adjacent to several isolated wetlands of over $1 / 4$ acre in size. Proposed harvest units 3,4 , and 5 are adjacent to isolated wetlands. 


\section{CLW Hidden Bugs Watershed area}

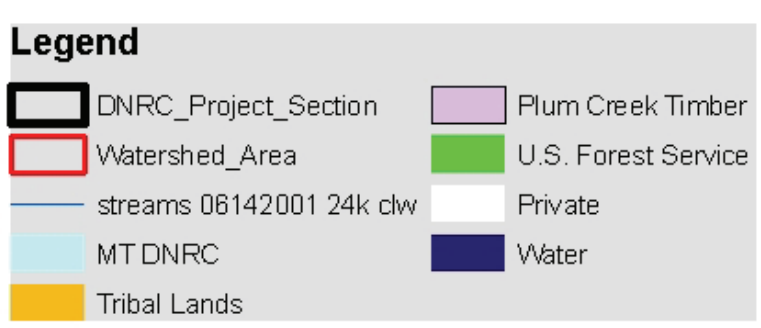

\section{Project Area}

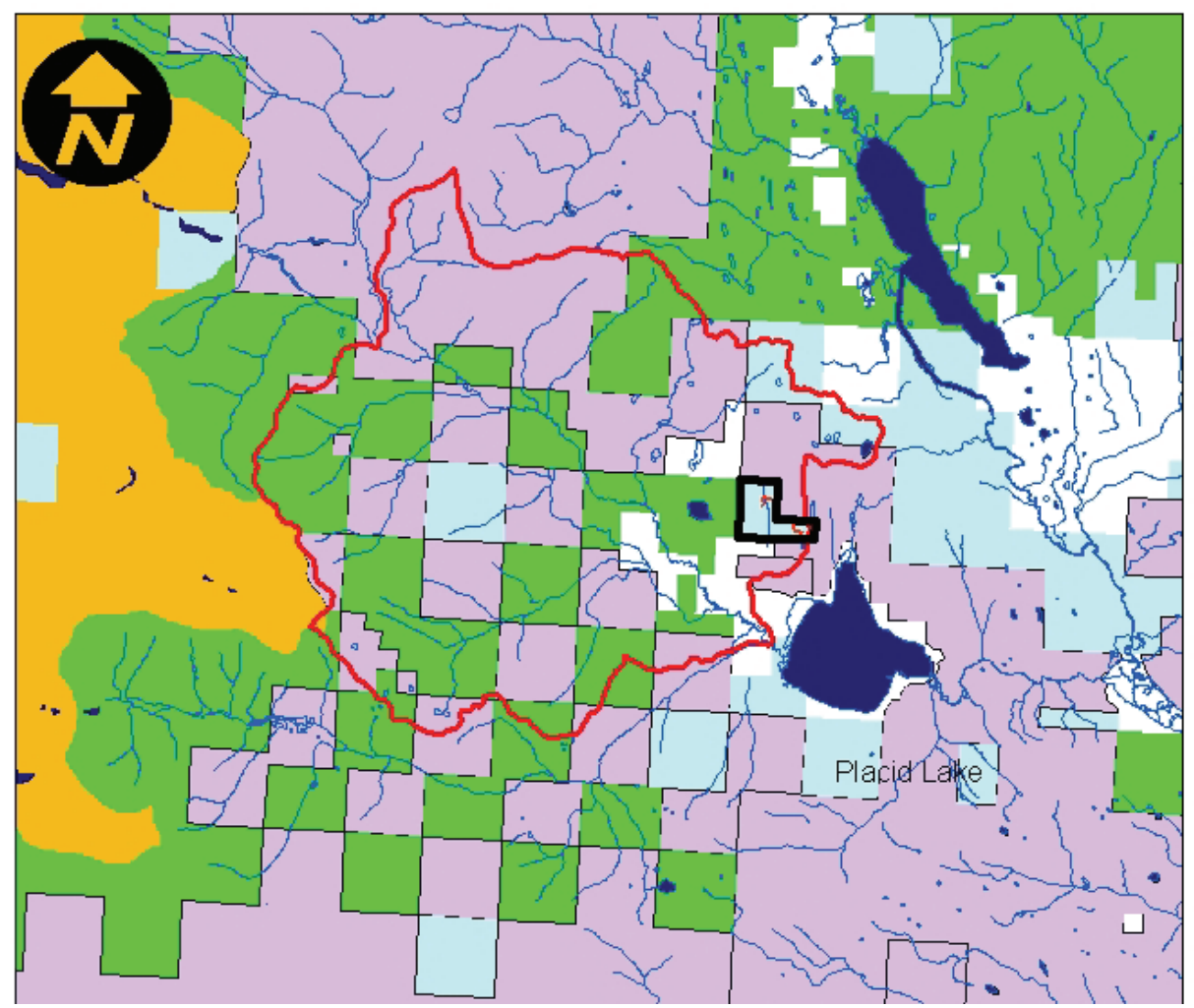

Geology \& Soils The proposed harvest area is located on a gently rolling terrain of glacial till and outwash deposits derived from Precambrian quartzite and argillite with high rock fragment residual soils on the glacially scoured mountain ridges. No unstable or unique geology occurs on the project area. The soils analysis area is limited to the DNRC ownership in Section 18, T16N, R15W.

Predominate forest soils are Winfall gravelly loams on 4-30\% slopes (small areas up to $40 \%$ ) forming in deep glacial till. Winfall soils are deep, well drained, gravelly loams and cobbly loams derived from quartzite and argillite. Topsoils are 4-6 inches of silt loam with intermittent deposits of volcanic ash silt loams. Soils on convex slopes may be shallower to fractured bedrock, but is common material of good quality for road construction. Erosion risk on disturbed soils is moderate.

Winfall soils are subject to rutting and compaction if operated on when wet. Winfall soils have a long season of use, once soils dry out in the spring. Displacement risk is moderate and can be 


\section{Attachment C \\ Soils, Watershed, and Fisheries Report}

mitigated by skid trail planning and minimizing disturbance to levels necessary to meet silvicultural goals. Predominate slopes of $10-40 \%$ are well suited to ground based skidding operations. Isolated wetlands include poorly drained soils of borohemists (MU26) and aquolls and aquepts (MU 6). The wetland areas as mapped are not continuous, but do interfinger into forested sites adjacent to proposed harvest unit 4 . The wetland soils have low bearing strength.

A commercial thinning was completed within this parcel in 1994. No BMP departures were noted and minimal soil effects occurred on these previous harvest areas. The 1994 harvest sites would not be reentered with this entry. Historic harvest effects within the proposed units are minimal and limited to a few major skid trails that are still apparent on less than $10 \%$ of the proposed harvest units.

\section{Water Quality Regulations}

Placid Creek watershed and Placid Lake have no pollution related impairments in the 2004 DEQ $303 \mathrm{~d}$ listings of impaired streams. There are no water rights for this parcel, no stream connectivity off-site to Placid Creek, or impacted beneficial uses. Isolated wetlands in this parcel are a source of water to free range cattle, wildlife and do provide wildlife habitat. Lower Placid Creek supports aquatic life, cold-water fisheries, and domestic beneficial uses with downstream beneficial uses of agriculture and industry.

The waters contained within the Lower Placid Creek watershed are classified as B-1 by the Montana Surface Water Quality Standards (ARM 17.30.623). The B-1 classification is for waters that are considered suitable for domestic use after conventional treatment, as well as recreation, swimming and bathing. They are also suitable for growth and propagation of salmonid fish and other associated aquatic life, waterfowl, furbearers, agricultural and industrial water supplies. Another criteria for a B-1 classification is; no increases are allowed above naturally occurring concentrations of sediment, settle able solids, oils or floating solids, which will or are likely to create a nuisance or render the waters harmful, detrimental or injurious to public health, recreation, safety, welfare, livestock, wild animals, birds, fish, or other wildlife. Naturally occurring includes conditions or materials present from runoff on developed where all reasonable land, soil and water conservation practices are applied (75-5-306(2) MCA).

\section{Water Quality}

A DNRC hydrologist completed a coarse filter evaluation of watershed conditions, road drainage and cumulative effects as outlined in the Forest Management Rules (ARM 36.11.423) concerning watershed management. The state parcel contains a short discontinuous segment of stream channel. The stream channel ends at a meadow adjacent to proposed harvest unit 4 . This stream segment does not deliver to Placid Creek and there is no potential for off-site water flow or sediment delivery. No water quality or wetland impacts were identified from previous harvest or during road reviews of the existing roads planned for use with proposed harvests.

The proposed haul route would use existing forest roads and county roads that are of high construction standard and well drained. Forest access roads across private ownership and road drainage were improved in 1988 Hidden Lake Timber Sale. Portions of the road system were closed with gates at selected sites for wildlife and to reduce road maintenance needs. Some segments of lower standard roads within the section include short steep grades that require maintenance grading to restore road surface drainage efficiency.

\section{Watershed Cumulative Effects}

The cumulative watershed effects analysis area considered the discontinuous drainage in the project section and access roads within the Lower Placid Creek Watershed. The coarse filter approach consisted of on-site evaluation of harvest areas and roads, and assessing the extent of past harvest activities through the use of maps and aerial photographs. Within the project area, ephemeral draws provide spring runoff to a short segment of approximately 400 feet of Class 2 stream associated with a wetland. This nearly flat, stream segment has minimal signs of surface flow and does not deliver to Placid Creek or another body of water. 
Mountain pine beetle infestations have caused patches of tree mortality and associated loss of tree canopy, evapo-transpiration potential and snow interception. The small patchy nature of the current tree mortality is unlikely to cause measurable changes in water yield or cumulative effects to water quality. A trend towards more extensive insect infestations and mortality or possibly wildfire could considerably reduce tree canopy and may increase water yield within the watershed in the future. Within the project area, increased water yield from tree mortality is unlikely to result in overland flow due to the dominantly coarse textured well drained soils, discontinuous and ephemeral drainages and isolated wetlands that would capture and retain any surface runoff. There is no stream connectivity from the project site to Lower Placid Creek or Placid Lake and thus low risk of watershed effects. No cumulative watershed effects from off-site sedimentation from roads or previous harvest units were identified in the project area.

\section{Fisheries}

Montana Fish, Wildlife and Parks expressed concern with the Lolo N.F. Hidden Lake Fuels Project relative to potential fisheries in the area. There are no fish bearing streams within the timber sale project area and no stream connectivity to the nearest fish bearing stream, Placid Creek or Placid lake and Hidden Lake. Placid Creek and Placid Lake although not affected, are within 1 mile of the project and support cold-water fisheries. Placid Lake supports sensitive fish species cutthroat trout and bull trout and other fish species including, rainbow trout, brook trout, kokanee salmon, and a number of other species (MFISH 2007 and FWP).

\section{Existing Noxious Weeds}

Noxious Weeds Spotted knapweed occurs along portions of the existing access road system mainly limited to roadsides, due to the competitive nature of native plants on forested sites.

\section{Environmental Effects of the Proposed Actions}

Alternative A The effects of the no action alternative would be the same as previously described under existing conditions for soils, water quality and fisheries.

Alternative B- The proposed prescription is to salvage harvest dead, dying and high-risk trees on up to 125 acres on moderate slopes of $5-40 \%$. The salvage harvest would be patchy in distribution reflective of the insect caused tree mortality and 40 to $50 \%$ of tree canopy would be maintained as mixed Douglas-fir and western larch trees. Unit 5 is located on gentle terrain and would have $65 \%$ of canopy removed that is dominated by lodgepole pine. Unit 4 includes areas of seasonal high water table and has boundaries on isolated wetlands. Approximately $1 / 2$ mile of low standard road would be constructed on moderate slopes, and about $1 / 4$ mile of road would be abandoned. No new stream crossings would be constructed. Several temporary spurs to landings would be constructed and stabilized after use. Maintenance grading would restore adequate drainage in all existing roads to meet BMP's.

\section{Soils Effects}

Primary soil concerns are potential for excessive surface disturbance and erosion with harvest operations. To maintain soil productivity, and promote conifer regeneration, BMP's and the listed mitigation measures would be implemented to minimize the area and degree of detrimental soil effects associated with harvest operations.

Mitigations include skid trail planning, limiting season of use to dry or frozen conditions, installing drainage where needed and retaining a portion of woody debris for nutrients and to control erosion on disturbed sites. The insect mortality has resulted in most trees shedding their needles, which helps return nutrients to the soil. It is desirable to maintain old and new coarse woody debris (>3" dia.) at $\sim 10-15$ tons/acre on the harvest units. Approximately $1 / 4$ mile of historic road (>40 yrs old) was poorly located up a dry draw and adjacent to a wetland and would not be used. This road is revegetated and relatively stable and would be abandoned and further obliterated with slash to prevent unauthorized ATV traffic. 


\section{Attachment C}

Soils, Watershed, and Fisheries Report

\section{Cumulative Effects to soils}

Previous selection harvest was limited to tree selection and salvage over 40 years ago. No previous harvest units would be reentered, and there is low risk of cumulative soil effects based on the partial harvest and mitigation planned (see mitigation measures) that would minimize the area of detrimental soil impacts to less than $15 \%$ of harvest units. This level of effects is consistent with DNRC soil monitoring (DNRC 2004). Large woody debris will be retained for nutrient cycling and long term productivity.. Mitigations include skid trail planning, season of use limitations and scarification only to the extent needed for silvicultural objectives. Roads would have adequate drainage installed and revegetated to control erosion on roads will help reduce erosion.

\section{Water Quality}

The proposed timber harvest, road construction and maintenance are expected to result in low risk of water quality impacts due to erosion and sediment delivery. DNRC would implement all applicable BMP's, Forest Management Rules and reasonable mitigation and erosion control practices during timber harvest, road maintenance and road use activities.

The proposed project would use existing roads and landings and construct approximately $1 / 2$ mile of low standard road on moderate slopes with adequate drainage and erosion control. About $1 / 4$ mile of road would be abandoned. No new road construction is planned near surface waters. On existing roads, grading would maintain the well-established grass roadways and avoid blading the surface except where needed to reshape existing drain-dips or install additional drain-dips where needed.

The discontinuous drainage that drains the project area ends in a meadow and there is no surface water connectivity or potential for sediment delivery off the project site to Placid Creek or Placid Lake. All wetlands, seeps and discontinuous stream segment would be avoided or protected. Protection boundaries (SMZ's and WMZ's) for restriction of equipment operations would be located around the short stream segment and wetlands to ensure protection of vegetative buffers, season of use limitations to minimize disturbance and prevent erosion or sediment delivery to the wetlands. For these reasons, there is low risk of direct or indirect impacts to water quality or beneficial uses as a result of the proposed action alternative.

\section{Cumulative Watershed Effects}

DNRC completed a coarse filter screening for watershed cumulative effects (ARM 36.11.423) for this permit including examining past projects for cumulative effects assessments. There is low risk of cumulative watershed impacts associated with water or sediment yield increases occurring from this proposal due to the following reasons. There are no streams with continuous surface delivery to another body of water. The small scale of this project represents $0.5 \%$ of the watershed and water yield would be similar to no action with removal of dead and dying lodgepole trees. The proposed harvest would retain mixed conifer species canopy. This is a moderate precipitation zone (23"/yr) with low runoff potential. Most existing roads are in fair to good condition requiring maintenance and no sediment delivery problems were identified for improvement.

\section{Fisheries Effects:}

With no action, there would be no effect on fisheries or fish habitat, as there are no streams on the project area that have connectivity to steams supporting fish.

With the action alternative, timber harvest of dead and dying lodgepole pine would be removed from sites adjacent to wetlands and a non-fish bearing stream segment. There is no risk of direct, indirect or cumulative impacts to fisheries associated with the proposed action alternative because there are no fish bearing streams or stream connectivity between the project area and known fish habitat in Placid Creek or downstream in Placid Lake. 


\section{Attachment C \\ Soils, Watershed, and Fisheries Report}

\section{Existing Sensitive Plants-}

No sensitive plants have been identified in the proposed harvest area and no effects are expected with this project. Howell's Gum Weed (Grindelia Howelli) is a sensitive plant known to occur in the general area. If Howell's Gumweed or other sensitive plants are identified during land management activities, DNRC will review options for mitigations for plant protection as feasible. Since no sensitive plants were identified in the proposed harvest area, this concern is dismissed from further analysis.

\section{Effects of Noxious Weed Management}

With no action, noxious weeds will continue to spread along roads and spread into dry site habitats unabated. The action alternative will involve ground-disturbing activities that have the potential to introduce or spread noxious weeds in susceptible habitat types. For the action alternative, an Integrated Weed Management (IWM) approach was considered. For this project: prevention, prompt revegetation and weed control measures are considered the most effective weed management treatments. Noxious weed density and occurrence would be similar or potential slight increase due to soil disturbance and decreased tree canopy. Control efforts will promote revegetation and emphasize treatment of any new noxious weeds. Implementation of IWM measures listed in the mitigations would reduce existing weeds and limit the possible spread of weeds. More weed control would occur compared to no-action alternative.

Recommended mitigation measures for the proposed project:

* Implement Forestry BMP's and FM Rules as the minimum standard for all operations with the proposed timber sale. The contractor and sale administrator should agree to a general skidding plan prior to equipment operations, with an emphasis to use existing trails where suitable.

* DNRC shall locate, mark and maintain suitable water resource protection boundaries (SMZ's, WMZ's) adjacent to streams and wetlands consistent with State Forest Land Management rules. A skidder with $50 \mathrm{ft}$. of winch line should be required for removal of trees inside the first $50 \mathrm{ft}$ of $S M Z$ or $W M Z$ as needed to prevent erosion, minimize disturbance and protects the integrity of the SMZ. A WMZ would be for adjacent wetlands on harvest Unit 4. Ground based operations within the WMZ would be limited to periods when soils were adequately dry or snow covered to prevent excessive soil displacement, compaction or erosion, consistent with ARM 36.11.426 (6).

* Limit equipment operations to periods when soils are dry, (less than $20 \%$ ), frozen, or snow covered, to minimize soil compaction and rutting, and maintain drainage features. Check soil moisture conditions prior to equipment start-up. Some moister conditions are accepted on harvest units where tractors remain on designated trails and timber will be winched to trails

* Down Woody Material: Target woody debris levels are to retain 5-15 tons/acre (old and new) coarse woody debris $>3$ " dia. well distributed on site and skid trails, for nutrient cycling and to control erosion. For fire safety the amount of CWD will be lower near the County road and around cabin sites.

* Install or restore adequate road drainage such as drain-dips as needed to control erosion concurrent with road use. All temporary spur roads will have adequate drainage maintained during use and will be closed. On this gentle ground, slash distributed on trails or temporary roads should be adequate to control erosion and prevent unauthorized use.

* All road and harvest equipment will be cleaned of plant parts, mud and weed seed to prevent the introduction of noxious weeds. Equipment will be subject to inspection by forest officer prior to moving on site.

* All newly disturbed soils on roads will be promptly reseeded to site adapted grasses to reduce weed encroachment and stabilize roads from erosion.

* Herbicide spraying may be applied for spot outbreaks of noxious weeds. All weed treatment measures would be implemented by a certified applicator according to herbicide label directions in accordance with applicable laws. Herbicides would not be applied where runoff could enter surface waters. 


\section{References}

Graham, Russell T.; Harvey, Alan;, Jurgensen, Martin; Jain,T.; 1994. Managing Coarse Woody Debris in Forests of the Rocky Mountains. Res. Paper INT-RP-477. Ogden, Utah: U.S.D.A., F.S., Intermountain Research Station, 12p.

Greenlee, Jack, TES Plant Biological Evaluation of Proposed Salmon Lake Analysis Area, Seeley Lake R.D. Draft 10/95, Lolo National Forest.

Missoula County Soil Survey, 1995, USDA, NRCS

Montana Department of Natural Resources and Conservation, 2006. Confusion Timber Salvage Environmental Assessment. Clearwater Unit Office.

Montana Department of Natural Resources and Conservation, 1983. Placid Lake Timber Sale Environmental Assessment. Clearwater Unit Office.

Montana Department of Natural Resources and Conservation, 1998. Quiet Stems Timber Sale Environmental Assessment. Clearwater Unit Office.

Montana Department of Natural Resources and Conservation, 2004. Collins, Jeffry DNRC Compiled Soil Monitoring Report on Timber Harvest Projects 1988-2004., Trust Land Management Division, Forest Management Bureau, Missoula, MT.

MFISH (Montana Fisheries Information System). 2006. Montana Fish, Wildlife and Parks and Natural Resource Information System. Helena, MT.

MTDEQ (Montana Department of Environmental Quality). 2004. Montana 2004 305(b) Report. Helena, MT. Natural Resource Information System. Helena, MT. 
23 March 2007

Michael McGrath

Wildlife Biologist, SWLO

\section{Hidden Bugs Timber Salvage \\ Wildlife Analysis}

\section{Chapter 1}

\section{Issues}

\section{Issues Studied in Detail}

\section{Endangered Species}

\section{Grizzly Bears}

Timber harvest and associated activities could alter habitat or create disturbance that could be detrimental to grizzly bears.

\section{Gray Wolves}

Timber harvest and associated activities could alter habitat or create disturbance that could be detrimental to gray wolves.

\section{Canada Lynx}

Timber harvest and associated activities could alter habitat or create disturbance that could be detrimental to lynx.

\section{Sensitive Species}

\section{Fisher}

Timber harvest and associated activities could alter habitat or create disturbance that could be detrimental to fishers.

\section{Flammulated Owl}

Timber harvest and associated activities could alter habitat or create disturbance that could be detrimental to flammulated owls.

\section{Pileated Woodpecker}

Timber harvest and associated activities could alter habitat or create disturbance that could be detrimental to pileated woodpeckers. 


\section{Big Game}

\section{White-tailed Deer and Elk}

Timber harvest and associated activities could alter habitat or create disturbance that could be detrimental to white-tailed deer and elk winter range and snow intercept cover.

\section{Other Species}

\section{Osprey}

Timber harvest and associated activities could alter habitat or create disturbance that could be detrimental to ospreys.

\section{Great Blue Herons}

Timber harvest and associated activities could alter habitat or create disturbance that could be detrimental to great blue herons.

\section{Issues Eliminated from Further Study}

\section{Endangered Species}

\section{Bald Eagles}

There is concern that the proposed action and resulting habitat alterations could create conditions that are detrimental to bald eagles. Bald eagles typically nest and roost in large diameter trees within 1 mile of open water. They are sensitive to a variety of human caused disturbances, ranging from residential activities to resource use and heavy equipment operation, among others (Montana Bald Eagle Working Group 1994). Bald eagle response to such activities may range from spatial and temporal avoidance of disturbance activities to total reproductive failure and abandonment of breeding areas (MBEWG 1994). While foraging, they typically perch within $500 \mathrm{~m}$ of shoreline habitat (Mersmann 1989); and roost in trees ranging in diameter from 12 to 39 inches and 49 to 200 feet in height (Stalmaster 1987). The nearest known bald eagle territories are located approximately 4 miles northeast, and 5 miles southeast of the project area. Due to the distance involved, there would be minimal risk of direct, indirect, and cumulative effects to this species as a result of the proposed action.

\section{Sensitive Species}

\section{Black-backed Woodpecker}


There is concern that timber harvest activities would disturb black-backed woodpeckers. This species is most often associated with areas that recently experienced stand-replacing fire (Hutto 1995). Approximately 4,200 acres of forestland burned in the 2003 Boles Meadow Fire, 4.6 miles southwest of the project area. Due to the proximity of suitable habitat nearby, the proposed action would likely have low risk of direct, indirect, or cumulative effects to this species.

\section{Peregrine Falcon}

There is concern that timber harvest activities would disturb nesting peregrine falcons. The nearest known peregrine falcon nest is located approximately 15 miles northwest of the project area. Thus, the proposed action would have minimal risk of direct, indirect, or cumulative effects to this species.

\section{Townsend's Big-eared Bat}

Townsend's big-eared bats occur in a wide variety of habitats, yet its distribution tends to be strongly correlated with the availability of caves and old mines for roosting habitat. Population concentrations occur in areas with substantial surface exposures of cavity forming rock, and in old mining districts (Pierson et al. 1999). This species is primarily a cave dwelling species that also roosts in old mine workings. It is a relatively non-migratory bat, for which no long-distance migrations have been reported. The Townsend's big-eared bat does not generally associate with other species in its roosts, particularly at maternity and hibernating sites. The generally accepted mitigations for this species (e.g., Pierson et al. 1999) recommend a $500 \mathrm{ft}$ radius buffer around mine and cave entrances to minimize disturbance around roost sites. Much of the mining activity in which adits or mine shafts are used occur $>0.75$ mile from the project area. As a result, there would be low risk of direct, indirect, or cumulative effects to this species as a result of the proposed action.

\section{Coeur d'Alene Salamander}

There is concern that timber harvest activities could affect this species. This species requires waterfall spray zones, talus, or cascading streams. There are no known areas of talus, waterfalls, or splash zones within the affected area. Thus, the proposed action would have low risk of direct, indirect, or cumulative effects to this species.

\section{Columbian Sharp-tailed Grouse}

There is concern that timber harvest activities could affect this species. The nearest known population of Columbian Sharp-tailed grouse occurs near Ovando, MT. Because of the distance involved, the proposed action would likely have low risk of direct, indirect, or cumulative effects to this species. 


\section{Common Loon}

The common loon is a fish-eating bird that breeds and nests on lakes and ponds. The nearest known nesting locations for loons are on Seeley and Salmon lakes. Because these areas are not connected through the stream network with the proposed project area, there is low risk of direct, indirect, or cumulative effects to common loons as a result of the proposed project and this species will not be analyzed further in this document.

\section{Harlequin Duck}

Harlequin ducks require white-water streams with boulder and cobble substrates, as well as dense riparian vegetation. Such conditions do not exist within, or downstream of the analysis area. Thus, there would be low risk of direct, indirect, or cumulative effects to this species.

\section{Mountain Plover}

There is concern that timber harvest activities could affect this species. The shortgrass prairie habitats, or heavily grazed taller grass prairie habitats, required by this species are not present within the harvest area. Thus, the proposed action would have low risk of direct, indirect, or cumulative effects to this species.

\section{Northern Bog Lemming}

There is concern that timber harvest activities could affect this species. The sphagnum meadows, bogs or fens with thick moss mats required by this species are not present within the harvest area. Thus, the proposed action would have low risk of direct, indirect, or cumulative effects to this species.

\section{Chapter 3-Affected Environment}

\section{Endangered Species}

\section{Grizzly Bears}

Grizzly bears are the largest terrestrial predators in North America, feasting upon deer, rodents, fish, roots and berries, as well as a wide assortment of vegetation (Hewitt and Robbins 1996). Depending upon climate, abundance of food, and cover distribution, home ranges for male grizzly bears in northwest Montana can range from $60-500 \mathrm{mi}^{2}$ (Waller and Mace 1997). The search for food drives grizzly bear movement, with bears moving from low elevations in spring to higher elevations in fall, as fruits ripen throughout the year. However, in their pursuit of food, grizzly bears can be negatively impacted through open roads (Kasworm and Manley 1990). Such impacts are manifested through habitat avoidance, poaching, and vehicle collisions. 
Grizzly bears are known to utilize areas near the project area. Within a 1,062 square mile analysis area that surrounds the project area, there are approximately 1,368 miles of open road and 3,400 miles of total road (open or closed), for road densities of 1.29 miles of open road per square mile (simple linear calculation), and 3.2 miles of total road per square mile (simple linear calculation). Currently, within the 310 acre affected parcel there is a total road density of approximately 5.41 miles of total road per square mile (simple linear calculation; 2.62 linear miles).

\section{Gray Wolves}

There currently are no known wolf packs within a 20-mile radius of the project area (U.S. Fish and Wildlife Service 2006 Interagency Wolf Report; Weekly wolf reports http://westerngraywolf.fws.gov/). However, there are unverified sightings of a wolf pack in the Jocko River drainage, approximately 8 miles west of the project area (Kent Laudon, Wolf Specialist, MT Fish, Wildlife \& Parks, personal communication, 5 March 2007). Cover, and road and prey densities likely have some influence on wolves (road densities reported under grizzly bear). For cumulative effects analysis, the analysis area will be the same as that of the grizzly bear. Mule deer, white-tailed deer, and elk are known to use the area. Currently, no known wolf den or rendezvous site is located within 1 mile of the project area.

\section{Canada Lynx}

Lynx are currently classified as threatened under the Endangered Species Act. In North America, lynx distribution and abundance is strongly correlated with snowshoe hares, their primary prey. Lynx foraging habitat has recently been characterized as having high horizontal cover, an abundance of shrub cover, large diameter trees during winter, and is typically in spruce-fir forest (Squires et al. 2006). Typically, lynx inhabit early- to mid-successional lodgepole pine, subalpine fir, and Engelmann spruce forest. For denning sites, the primary component appears to be large woody debris, in the form of down logs, root wads, and rock piles (Koehler 1990) surrounded by high horizontal cover (Squires et al. 2006, Squires and Laurion 2000, Mowat et al. 2000). These den sites are usually in mature, mesic forests on northeast aspects. Lynx also den along the edges of regenerating forests where trees have blown down into jackstrawed piles of woody debris (Squires et al. 2006, Ruediger et al. 2000).

Elevations in the project area range from 4,200 to 4,521 feet, and approximately 117 acres of suitable habitat occur in the project area. Snowshoe hares are important lynx prey and are associated with dense young lodgepole pine stands, as well as mature stands with subalpine fir understories. An approximately 57,089 acre analysis area was developed for lynx that encompassed the project area and utilized topography and habitat for its creation. While the analysis area 
encompasses approximately 29,787 acres of habitat contained within an area known for lynx utilization (a 90\% kernel, based on 2800 GPS and aerial telemetry locations collected from 75 lynx between 1998 and 2006; Squires and Kolbe, personal communication, 23 February 2007), the project area is not included within the $90 \%$ kernel (it is, however, located $<1$ mile from this area). Table 1 describes the land ownership within the 57,089 acre cumulative effects analysis area.

Table 1. Land ownership within the 57,089 acre lynx analysis area.

\begin{tabular}{lr}
\hline Land Owner & Acres \\
\hline Montana Fish, Wildlife \& Parks & 31 \\
Water & 1,387 \\
Private Lands & 2,583 \\
Flathead Tribal Lands & 3,411 \\
Montana DNRC & 6,337 \\
U.S. Forest Service & 16,650 \\
Plum Creek & 26,688 \\
\hline
\end{tabular}

\section{Sensitive Species}

\section{Fisher}

The fisher is a medium-sized animal belonging to the weasel family. Fishers prefer dense, lowland spruce-fir forests with high canopy closure, and avoid forests with little overhead cover and open areas (Powell 1978, Powell 1977, Kelly 1977, Clem 1977, Coulter 1966). For resting and denning, fishers typically use hollow trees, logs and stumps, brush piles, and holes in the ground (Coulter 1966, Powell 1977).

Within a 4-mile radius of the project area, there are approximately 5,169 acres of fisher preferred habitat types on School Trust and USFS parcels. Of these acres, approximately 117 acres occur within the project area. The Montana Natural Heritage Database reports at least 2 fisher sightings within a 4-mile radius of the project area. No class 1 or class 2 streams flow through the affected parcel. However, an unnamed stream may provide habitat for fisher.

\section{Flammulated Owl}

The flammulated owl is a tiny forest owl that inhabits warm-dry ponderosa pine and cool-dry Douglas-fir forests in the western United States and is a secondary cavity nester. Nest trees in 2 Oregon studies were 22-28 inches dbh (McCallum 1994). Habitats used have open to moderate canopy closure (30 to 50\%) with at least 2 canopy layers, and are often adjacent to small clearings. It subsists primarily on insects and is considered a sensitive species in Montana. Periodic underburns may contribute to increasing habitat suitability for flammulated owls because low intensity fires would reduce understory density of seedlings and 
saplings, while periodically stimulating shrub growth. Within the project area there are approximately 188 acres of flammulated owl preferred habitat types.

\section{Pileated Woodpecker}

The pileated woodpecker is one of the largest woodpeckers in North America (1519 inches in length), feeding primarily on carpenter ants (Camponotus spp.) and woodboring beetle larvae (Bull and Jackson 1995). The pileated woodpecker nests and roosts in larger diameter snags, typically in mature to old-growth forest stands (McClelland et al. 1979, Bull et al. 1992, McClelland et al. 1979). Due primarily to its large size, pileated woodpeckers require nest snags averaging 29 inches dbh, but have been known to nest in snags as small as 15 inches dbh in Montana (McClelland 1979). Pairs of pileated woodpeckers excavate 2-3 snags for potential nesting sites each year (Bull and Jackson 1995). Snags used for roosting are slightly smaller, averaging 27 inches dbh (Bull et al. 1992). Overall, McClelland (1979) found pileated woodpeckers to nest and roost primarily in western larch, ponderosa pine, and black cottonwood. The primary prey of pileated woodpeckers, carpenter ants, tend to prefer western larch logs with a large end diameter greater than 20 inches (Torgersen and Bull 1995). Thus, pileated woodpeckers generally prefer western larch and ponderosa pine snags $>$ 15 inches dbh for nesting and roosting, and would likely feed on downed larch logs with a large end diameter greater than 20 inches.

Within the affected parcel, there are approximately 232 acres that are contain ponderosa pine or western larch, with potential for suitable pileated woodpecker habitat (SLI database). The cumulative effects analysis area will encompass the project area and a 1-mile radius surrounding the parcel. Pileated woodpeckers have been sighted within the cumulative effects analysis area (Montana Natural Heritage Database).

\section{Big Game}

\section{White-tailed Deer and Elk}

Densely stocked thickets of conifer regeneration and overstocked mature stands provide thermal protection and hiding cover for deer and elk in winter, which can reduce energy expenditures and stress associated with cold temperatures, wind, and human-caused disturbance. Areas with densely stocked mature trees are also important for snow interception, which makes travel and foraging less stressful for deer during periods when snow is deep. Dense stands that are well connected provide for animal movements across wintering areas during periods with deep snow, which improves their ability to find forage and shelter under varied environmental conditions. Thus, removing cover that is important for wintering deer through forest management activities can increase their energy expenditures and stress in winter. Reductions in cover could ultimately result in a reduction in 
winter range carrying capacity and subsequent increases in winter mortality within local deer and elk herds.

Within the project area, there are approximately 240 acres of densely canopied forest, which could provide snow-intercept, and possibly thermal cover for deer and elk. Within the larger cumulative effects analysis area, an approximately 66,157 acre area, there are approximately 17,283 acres of snow intercept/thermal cover (determined using color orthophotographs from 2005). For security cover (amount of habitat capable of holding elk that is at least 250 acres in size and $\geq$ 0.5 mile from an open road; Hillis et al. 1991), there is no security cover within the project area due to small patch size, and 7,698 acres (11.6\% of cumulative effects analysis area) within the cumulative effects analysis area. Additionally, this parcel has not been leased for grazing, but it has been leased for nonexclusive outfitting for hunting.

\section{Other Species}

\section{Osprey}

Osprey are a highly migratory raptor that breed in Montana from late Spring through mid-Summer. The primary diet of osprey is fish, with non-fish prey (e.g., frogs, crustaceans, turtles, small mammals, birds) rarely exceeding two percent of identified foods (Sherrod 1978 in Johnsgard 1990). It has been suggested (Beebe 1974 in Johnsgard 1990) that breeding habitat needs include only three components: fish that move slowly near the water surface, an ice-free season long enough to permit reproduction, and elevated or inaccessible nest sites, or at least freedom from molestation during the breeding season. In Montana, the breeding season occurs from April through the end of July each year. Reasons for population declines are typically cited as excessive human disturbance or destruction, declining fishery stocks, and persistent pesticides (Evans 1982 in Johnsgard 1990). An osprey nest was located approximately 100 yards south of the project area in 2004, and has been used in subsequent years (H. Stabins, Plum Creek Timber Co. Wildlife Biologist, personal communication, 19 February 2007).

\section{Great Blue Herons}

Great blue heron populations appear secure in Montana and they do not have sensitive, Threatened or Endangered status. Herons often nest in cottonwoods along riparian areas, and in coniferous forests on drier upland sites. Herons typically select the largest trees for nesting and they may nest singly or in rookeries. Rookeries tend to be fairly dynamic, and they occasionally abandon existing nest sites, or move to nearby locations in response to unknown factors. Nest sites occur in a wide range of locations that are subject to varying degrees of human activity. Several rookeries occur in western Montana within severalhundred feet of major interstate highways. Herons normally lay 3-7 eggs and their 
incubation period is about 25-29 days. Young abandon the nest about 60-90 days after hatching. Most young fledge by the end of July during most years.

While herons do construct and inhabit rookeries at times in areas with high levels of human activity, they can be sensitive to various forms of human disturbance (Vos 1984). Nest and colony abandonments increase with increased visits by humans (Drapeau et al. 1984) and with road building and logging activity within 547 yards $(0.5 \mathrm{~km}$; Werschkul et al. 1976 in Butler 1992). However, herons appear to be relatively persistent in their attempts to use existing rookeries following disturbance. A great blue heron rookery was located approximately 125 yards from the southern boundary of the affected parcel. This rookery was first discovered by Plum Creek in January 2002, prior to timber harvesting. The nest trees and several alternate/potential nest trees were retained in a patch during a harvest thinning. Subsequent to the timber harvest, the rookery has been active from 2003 through 2006, with a range of 4 to 13 nest structures in 1 to 4 ponderosa pines (H. Stabins, Plum Creek Timber Co. Wildlife Biologist, personal communication, 19 February 2007).

\section{Chapter 4-Environmental Consequences}

\section{Endangered Species}

\section{Grizzly Bears}

No Action: Under this alternative, no harvest, road construction, or road abandonment would occur at this time and no immediate changes would be expected. However, mountain pine beetle activity would likely continue to infest and kill lodgepole and ponderosa pine within the DNRC ownership and surrounding area. Some of the dead trees would likely be blown down, creating openings within the stands. Over time, some natural conifer regeneration would probably establish in areas with a seed source and favorable microclimate. During the period between tree death and regeneration, vegetative screening would likely be retained in areas through the presence of tree boles from lodgepole pine and ponderosa pine snags. Due to the absence of locked gates, it may be possible for trespass of motorized vehicles during this time. While there may be motorized vehicle access, the presence of vegetative screening may partially mitigate the effects of motorized access. Thus, there may be low risk of direct, indirect, or cumulative effects to grizzly bears as a result of the no action alternative.

Timber Harvest Alternative: The proposed action would harvest lodgepole pine on 125 acres, construct approximately 0.5 mile of new road, abandon approximately 0.25 mile of existing road, and may install one or more gates to restrict motorized access. As a result, visual screening would be reduced, particularly in the southeast corner of the parcel (proposed harvest unit 5), which is predominately a lodgepole pine stand and is surrounded on 3 sides by a Plum Creek seed tree harvest. Additionally, due to the level topography along the 
southeastern parcel boundary, the proposed harvest would likely increase motorized access to this portion of the parcel by ATV's and other off-road vehicles. As partial mitigations to the proposed action, because of the presence of several wetland and riparian features within the affected parcel, it is recommended that several 0.5 to 1 acre patches be strategically placed (e.g., around wetland/riparian features, near roads, etc.) within harvest unit 5 to break up sight distance and reduce the possibility of off-road travel until successful regeneration has occurred. The proposed road activities would likely see a net increase of approximately 0.25 mile of road ( 0.5 mile road construction and 0.25 mile of road abandonment. As a result, there would be an increase in total road density within the project area from approximately 5.41 miles per square mile to approximately 5.93 miles per square mile. Should the proposed action be implemented without the recommended mitigations, there would likely be low to moderate risk of direct, indirect and cumulative effects to grizzly bears as a result of the proposed action, the proposed USFS fuels reduction, and past timber harvest on adjacent Plum Creek parcels. If proposed mitigations to reduce sight distance and reduce off-road travel on flat ground are implemented, the risk of direct, indirect, and cumulative effects may be reduced to low.

\section{Gray Wolves}

No Action: Similar to the effects for grizzly bears under this alternative, no harvest at this time would retain vegetative screening and help reduce off-road travel within the parcel. Additionally, the unharvested timber may hold deer and elk due to reduced sight distances, and provide foraging opportunities for wolves. As a result, there would likely be low risk of direct, indirect, or cumulative effects to wolves as a result of the no action alternative.

Timber Harvest Alternative: As described for the grizzly bear under the timber harvest alternative, the proposed action would make portions of the project area more accessible to off-road vehicles and reduce vegetative screening.

Additionally, the proposed action would reduce snow intercept cover within the proposed harvest units, which would likely reduce the capacity of the affected parcel to provide winter cover for deer and elk. Should it be established that wolves utilize this area, these potential effects may increase wolf foraging opportunities while increasing wolf vulnerability to negative human interactions. Wolf foraging opportunities may increase as a result of the proposed action because sight distance and snow depth would be increased in the proposed harvest units, which would make deer and elk more susceptible to predation. However, these same conditions may leave wolves more vulnerable to being shot. As partial mitigations to the proposed action, it is recommended that several 0.5 to 1 acre patches be strategically placed (e.g., around wetland/riparian features, near roads, etc.) within harvest unit 5 to break up sight distance and reduce the possibility of off-road travel until successful regeneration has occurred. Should it be established that wolves utilize this area and the recommended mitigations be implemented, the proposed action would likely have low risk of direct, indirect, or cumulative effects to wolves. If the recommended mitigations are not 
implemented, the risk of direct, indirect, or cumulative effects would likely range between low and moderate.

\section{Canada Lynx}

No Action: Under this alternative, no harvest, road construction, or road abandonment would occur at this time and no immediate changes would be expected. However, mountain pine beetle activity would likely continue to infest and kill lodgepole and ponderosa pine within the DNRC ownership and surrounding area. Some of the dead trees would likely be blown down, creating openings within the stands. Over time, some natural conifer regeneration would probably establish in areas with a seed source and favorable microclimate. Such combinations of resulting blow down, root wads, and conifer regeneration may result in denning habitat and patches of foraging habitat for lynx. As a result, there may be a benefit to lynx from the no action alternative in 15 to 30 years. However, in the same time frame there is also potential for a stand replacing fire to burn through the affected parcel and remove the same features that would be beneficial to lynx.

Timber Harvest Alternative: Under the proposed action of harvesting approximately 125 acres of lodgepole pine, approximately 91 acres of lynx habitat (currently classified as "Other") would be converted to temporary non-lynx habitat, with approximately 26 acres retained in suitable condition for lynx. Due to the proximity of the affected parcel to an area with high lynx use $(<1$ mile), the project area likely receives use by lynx to some degree. However, because there is little of a seedling and sapling component to the forest within the parcel, foraging opportunities for lynx are likely reduced. Such conditions are generally more abundant on adjacent USFS parcels immediately to the west. Perhaps the single-most effect to lynx from the proposed action would be the removal of lodgepole pine that would eventually fall over and possibly jackstraw and create potential denning sites. Should the recommended mitigations of grizzly bears and wolves ( 0.5 to 1 acre retention patches in harvest unit 5 ) be implemented, such conditions may occur in the future, albeit in a reduced amount. Adjacent to the affected parcel, the USFS has proposed a fuels reduction project that would thin the forest and would likely still retain forest characteristics important to lynx. There would likely be low to moderate risk of direct, indirect, and cumulative effects to lynx as a result of the proposed action, as well as the cumulative effects of the proposed USFS fuels reduction project and past harvest on Plum Creek Timber lands within the analysis area.

\section{Sensitive Species}

Fisher

No Action: Under this alternative, no harvest, road construction, or road abandonment would occur at this time and no immediate changes would be expected. However, mountain pine beetle activity would likely continue to infest and kill lodgepole and ponderosa pine within the DNRC ownership and 
surrounding area. Such activities would reduce stand crown closures, and subsequently reduce fisher habitat suitability. Eventually, some of the dead trees would likely be blown down, creating openings within the stands. Over time, some natural conifer regeneration would probably establish in areas with a seed source and favorable microclimate. Such combinations of resulting blow down, root wads, and conifer regeneration may result in more desirable habitat characteristics for fishers. Thus, under a no action alternative, natural processes would reduce fisher habitat suitability within the affected parcel. Fisher habitat suitability would likely be restored or improved over time (likely $>50$ years) once stands had regenerated, crown closures had been restored, and vertical structure within the stands had been re-established. At the scale of the cumulative effects area (a 4 mile radius from the parcel), much of the available fisher habitat has previously been fragmented by past harvest on Plum Creek timber lands, while connective corridors remain on blocked school trust lands south and west of Seeley Lake. Because of the checkerboard ownership (Plum Creek, USFS, DNRC) throughout most of the analysis area, much of the forestland would likely become suitable habitat for fisher around the same time, once it has regenerated. Thus, due to the currently fragmented nature of the analysis area, there would likely be minimal to low risk of direct and indirect effects to fisher, and like low to moderate risk of cumulative effects due to the extensive fragmented nature of the current landscape.

Timber Harvest Alternative: The proposed action would harvest approximately 33 acres of the 117 acres of fisher habitat in the affected parcel. Much of the remaining habitat would be along a riparian area and connected to habitat in the adjoining USFS parcel to the west. While the USFS currently has proposed the Hidden Lake Fuels Reduction project in the adjacent parcel on 388 acres, the proposal would retain 40 to $60 \%$ of the overstory and 10 to $40 \%$ of the understory. While both proposed actions would likely further degrade habitat suitability for fishers within the project and cumulative effects analysis areas, such actions would likely still retain suitable fisher habitat characteristics. The proposed action would also implement SMZ boundaries and wetland management zone rules, where appropriate. As such, important fisher habitat would be maintained. Given the level of habitat fragmentation within the cumulative effects analysis area discussed for fisher under the No Action alternative, and the extent of the proposed action, there would likely be low to moderate risk of direct, indirect, and cumulative effects to fisher due to the additional fragmentation of habitat.

\section{Flammulated Owl}

No Action: Under this alternative, no harvest, road construction, or road abandonment would occur at this time and no immediate changes would be expected. Much of the potential flammulated owl habitat lies outside of the area affected by mountain pine beetle activity. However, for those areas affected by beetle activity, beetles would continue to infest and kill lodgepole and ponderosa pine. Such activities would likely create future potential nesting sites through 
creation of forest openings and larger diameter snags (ponderosa pine). Within openings that would likely be created, some natural conifer regeneration would become established, further augmenting flammulated owl habitat. As a result, there would likely be positive direct and indirect effects to flammulated owls under the no action alternative. On the adjacent USFS parcel, the proposed Hidden Lake Fuels Reduction project would reduce crown closure, but would also likely remove potential nesting snags as part of the fuels reduction. The adjacent Plum Creek lands currently do not contain suitable flammulated owl habitat due to past harvest. As a result, the no action alternative would likely have positive cumulative effects for this species because it would eventually augment habitat in the long term.

Timber Harvest Alternative: The proposed action would harvest timber in approximately 34 acres of flammulated owl preferred habitat types (Pfister et al. 1977), removing the lodgepole pine. As a result, stand density would be decreased in the affected stands, enabling natural conifer regeneration to occur. Provided suitable nesting snags occur nearby, such action could produce suitable flammulated owl foraging habitat within 20 years, as this species prefers forests with scattered openings and regeneration for foraging. Currently, the affected stands are likely too dense for nesting by this species. Thus, the proposed action would likely have positive direct and indirect effects for this species in the long term.

Similar to the no action alternative, the proposed Hidden Lake Fuels Reduction project, on adjacent USFS lands, would reduce crown closure, but would also likely remove potential nesting snags as part of the fuels reduction. The adjacent Plum Creek lands currently do not contain suitable flammulated owl habitat due to past harvest. As a result, the proposed action would likely have positive cumulative effects for this species because it would eventually augment habitat in the long term.

\section{Pileated Woodpecker}

No Action: Under this alternative, no harvest, road construction, or road abandonment would occur at this time and no immediate changes would be expected. However, mountain pine beetle activity would likely continue to infest and kill lodgepole and ponderosa pine within the DNRC ownership and surrounding area. Such activities would reduce stand crown closures and create numerous lodgepole and ponderosa pine snags. A few of the resulting ponderosa pine snags may be of sufficient size for nesting. However, with the infestation levels, many other habitat characteristics (e.g., canopy closure) that are influential on nest site suitability for this species would be negatively impacted. Foraging opportunities would likely be created with the abundance of lodgepole pine snags, and eventually downed logs that would be a source for carpenter ants and woodboring beetles. Thus there may be negative direct and indirect effects to pileated woodpeckers as a result of the no action alternative. 
The proposed Hidden Lake Fuels Reduction project, on adjacent USFS lands, would reduce crown closure, but may also remove potential nesting snags as part of the fuels reduction. However, the USFS' project area would likely retain suitable nesting habitat characteristics post-harvest. The affected DNRC parcel would likely serve as foraging habitat for pileated woodpeckers that might nest on the adjacent USFS parcel. Finally, the adjacent Plum Creek lands currently do not contain suitable pileated woodpecker habitat due to past harvest. As a result, the no action alternative may have positive cumulative effects for this species because it may enhance foraging opportunities through retention of bug-killed trees and eventually downed logs.

Timber Harvest Alternative: The proposed action would harvest approximately 125 acres from 232 acres of potential pileated woodpecker habitat. While both the no action and proposed action alternatives would reduce crown closure, the proposed action would remove lodgepole pine that would likely become foraging substrate for this species. Thus, the proposed action would reduce foraging opportunities for pileated woodpeckers until the site has successfully regenerated and those trees have achieved sufficient size to provide foraging opportunities (approximately 40 years). As partial mitigation, the proposed action would retain at least 1 snag and 1 snag recruit per acre that are at least 21 inches dbh, or of the largest available size class, as per ARM 36.11.411. Thus, there would likely be low to moderate risk of direct and indirect effects to pileated woodpeckers as a result of the proposed harvest that would reduce foraging opportunities for this species. Given past harvest activities on adjacent Plum Creek lands, the proposed harvest's removal of lodgepole pine would further reduce current and future foraging opportunities for this species. Thus, there would likely be low to moderate risk of cumulative effects to pileated woodpeckers as a result of the proposed action.

\section{Big Game}

White-tailed Deer and Elk

No Action: Under this alternative, no harvest, road construction, or road abandonment would occur at this time and no immediate changes would be expected. However, mountain pine beetle activity would likely continue to infest and kill lodgepole and ponderosa pine within the DNRC ownership and surrounding area. Such activities would reduce stand crown closures, and subsequently reduce the ability of the affected areas to provide thermal cover for wintering ungulates. This process may take 5 to 10 years. As a result, the no action alternative would likely have moderate risk of direct, indirect, and cumulative effects to thermal cover for deer and elk in conjunction with past timber harvest on nearby Plum Creek lands.

Timber Harvest Alternative: The proposed action would harvest 125 acres of lodgepole pine from the approximately 240 acres of densely canopied forest that provides snow-intercept and thermal cover for deer and elk within the affected 
parcel. However, as discussed under the no action alternative, these same acres would likely become defoliated within the next 10 years, which would have similar effects as the proposed action. Within the cumulative effects analysis area, this reduction in snow-intercept/thermal cover would result in $<1 \%$ reduction in such cover (from 17,283 acres to 17,158 acres), and no reduction in security cover. However, such action would further fragment the remaining cover within the analysis area, forcing wintering ungulates onto school trust lands near Seeley Lake, and to higher elevations to the west on USFS lands. As a result, the proposed action, like the no action alternative, would likely have moderate risk of direct, indirect, and cumulative effects to snow-intercept and thermal cover for deer and elk in conjunction with past timber harvest on nearby Plum Creek lands.

\section{Other Species}

\section{Osprey}

No Action: No changes from existing conditions would be expected for ospreys under the no action alternative because forest cover near the nest would not unduly influence the suitability of the site for nesting.

Timber Harvest Alternative: The proposed action would harvest lodgepole pine on 125 acres, conduct road maintenance, and construct approximately 0.5 mile of road within the affected parcel. Due to the osprey's flexibility with respect to nesting habitat, loss of vegetation $>100$ yards from the nest would not likely impart negative effects to this species. However, osprey may be sensitive to excessive human disturbance. For these reasons, it is recommended that mechanical operations (i.e., harvesting, decking, and road construction) associated with Unit 5 occur between August 1 and March 31. Log hauling along established roads that are currently screened from the nest by trees within Unit 5 would be permissible due to the vegetative screening. Pending implementation of the proposed mitigative measures, there would likely be low risk of direct, indirect, and cumulative effects to the osprey pair as a result of the proposed action.

\section{Great Blue Herons}

No Action: No changes from existing conditions would be expected for great blue herons under the no action alternative because forest cover near the nest would not unduly influence the suitability of the site for nesting.

Timber Harvest Alternative: Similar to the environmental effects for osprey, given the habitat the existing great blue heron rookery currently inhabits, the loss of lodgepole pine on the adjacent school trust parcel would likely have low risk of direct, indirect, or cumulative effects. However, the mechanical operation associated with the proposed action may pose greater risk to the rookery, if such action occurred during the breeding season. To minimize the likelihood of nest abandonment, it is recommended that a 547 yard $(0.5 \mathrm{~km})$ buffer from the rookery be implemented to limit mechanical operations (i.e., harvesting, decking, and road 
construction) to a period between August 1 and March 31 in Unit 5. Log hauling along established roads that are currently screened from the rookery by trees within Unit 5 would be permissible outside of this time frame due to the vegetative screening. Should such mitigations be implemented with the proposed action, there would likely be low risk of direct, indirect, and cumulative effects to great blue herons.

\section{Literature Cited}

Clem, M. K. 1977. Food habits, weight changes and habitat use of fisher Martes pennanti during winter. M. S. Thesis, University of Guelph, Guelph, Ontario.

Coulter, M. W. 1966. Ecology and management of fishers in Maine. Dissertation, Syracuse University, Syracuse, New York.

Hewitt, D. G. and C. T. Robbins. 1996. Estimating grizzly bear food habits from fecal analysis. Wildlife Society Bulletin 24:547-550.

Hillis, J. M., M. J. Thompson, J. E. Canfield, L. J. Lyon, C. L. Marcum, P. M. Dolan, and D. W. McCleerey. 1991. Defining elk security: the Hillis paradigm. Pages 3843 in A. G. Christensen, L. J. Lyon, and T. N. Lonner, compilers. Proceedings of the Elk Vulnerability Symposium. Montana State University, Bozeman, Montana.

Hutto, R. L. 1995. Composition of bird communities following stand-replacement fires in northern Rocky Mountain (U.S.A.) conifer forests. Conservation Biology 9:1041-1058.

Johnsgard, P. A. 1990. Hawks, eagles, \& falcons of North America. Smithsonian Institution Press, Washington, D. C.

Kasworm, W. F. and T. L. Manley. 1990. Road and trail influences on grizzly bears and black bears in northwest Montana. International Conference on Bear Research and Management 8:79-84.

Kelly, G. M. 1977. Fisher (Martes pennanti) biology in the White Mountain National Forest and adjacent areas. Dissertation, University of Massachusetts, Amherst, Massachusetts.

Koehler, G. M. 1990. Population and habitat characteristics of lynx and snowshoe hares in north central Washington. Canadian Journal of Zoology 68:845-851.

McCallum, D. A. 1994. Flammulated owl (Otus flammeolus). Pages 1-24 in The Academy of Natural Sciences; The American Ornithologists' Union, Philadelphia, Pennsylvania.

McClelland, B. R., S. S. Frissell, W. C. Fischer, and C. H. Halvorson. 1979. Habitat 
management for hole-nesting birds in forests of western larch and Douglas-fir. Journal of Forestry 77:480-483.

Mersmann, T. J. 1989. Foraging ecology of bald eagles on the northern Chesapeake Bay with an examination of techniques used in the study of bald eagle food habits. M. S. Thesis, Virginia Polytechnic Institute and State University, Blacksburg, Virginia.

Montana Bald Eagle Working Group. 1994. Montana bald eagle management plan. Montana Bald Eagle Working Group (Montana bald eagle management plan. U. S. Department of Interior, Bureau of Land Management, Billings, Montana.

Mowat, G., G. Poole, and M. O'Donoghue. 2000. Ecology of lynx in northern Canada and Alaska. Pages 265-306 in L. F. Ruggiero, K. B. Aubry, S. W. Buskirk, G. M. Koehler, C. J. Krebs, K. McKelvey, and J. R. Squires (eds.). Ecology and conservation of lynx in the United States. U. S. Department of Agriculture, Forest Service, Rocky Mountain Research Station, Ft. Collins, Colorado. General Technical Report RMRS-GTR-30WWW.

Pfister, R. D., B. L. Kovalchik, S. F. Arno, and R. C. Presby. 1977. Forest habitat types of Montana. U. S. Department of Agriculture, Forest Service, Intermountain Forest and Range Experiment Station, Ogden, Utah.

Pierson, E. D., M. C. Wackenhut, J. S. Altenbach, P. Bradley, P. Call, D. L. Genter, C. E. Harris, B. L. Keller, B. Lengus, L. Lewis, B. Luce, K. W. Navo, J. M. Perkins, S. Smith, and L. Welch. 1999. Species conservation assessment and strategy for Townsend's big-eared bat (Corynorhinus townsendii and Corynorhinus townsendii pallescens). Idaho Department of Fish and Game, Boise, Idaho.

Powell, R. A. 1977. Hunting behavior, ecological energetics and predator-prey community stability of the fisher (Martes pennanti). Dissertation, University of Chicago, Chicago, Illinois. $1: 28-34$.

1978. A comparison of fisher and weasel hunting behavior. Carnivore

Ruediger, B., J. Claar, S. Gniadek, B. Holt, L. Lewis, S. Mighton, B. Naney, G. Patton , T. Rinaldi, J. Trick, A. Vandehey, F. Wahl, N. Warren, D. Wenger, and A. Williamson. 2000. Canada lynx conservation assessment and strategy. U. S. Department of Agriculture, Forest Service, Missoula, Montana. R1-00-53.

Squires, J. R. and T. Laurion. 2000. Lynx home range and movements in Montana and Wyoming: preliminary results. Pages 337-349 in L. F. Ruggiero, K. B. Aubry, S. W. Buskirk, G. M. Koehler, C. J. Krebs, K. McKelvey, and J. R. Squires (eds.). Ecology and conservation of lynx in the United States. U. S. Department of Agriculture, Forest Service, Rocky Mountain Research Station, Ft. Collins, Colorado. General Technical Report RMRS-GTR-30WWW. 
Squires, J. R., L. F. Ruggiero, J. A. Kolbe, and N. J. DeCesare. 2006. Lynx ecology in the Intermountain West. USDA Forest Service, Rocky Mountain Research Station, Missoula, Montana.

Stalmaster, M. V. 1987. The bald eagle. Universe Books, New York, New York.

Waller, J. S. and R. D. Mace. 1997. Grizzly bear habitat selection in the Swan Mountains, Montana. Journal of Wildlife Management 61:1032-1039. 


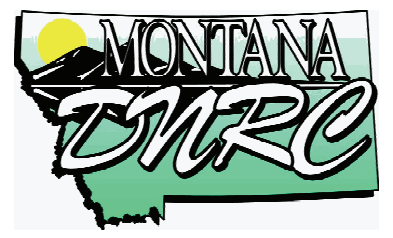

MONTANA DEPARTMENT OF NATURAL RESOURCES AND CONSERVATION

\author{
CLEARWATER UNIT \\ BOX 48455 SPERRY GRADE ROAD \\ GREENOUGH, MT. \\ 59823-9635
}

(406) 244-5857

Persons with disabilities who need an alternative, accessible format of this document should contact the DNRC at the above address or phone number.

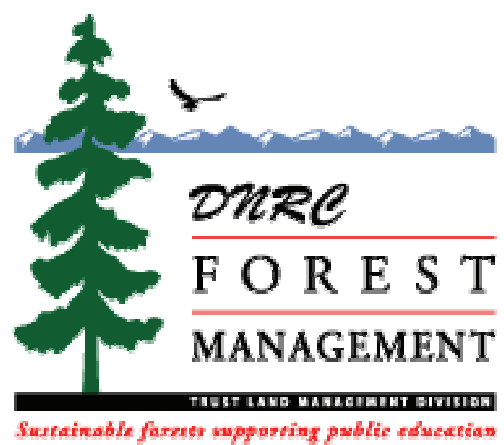

20 copies of this document were published at an estimated cost of $\$ 15.00$ per copy.

The total cost includes $\$ 13.00$ for printing/binding and \$2.00 for distribution. 